$10-2016$

\title{
Editors' Introduction
}

\author{
Christian Gudehus \\ Ruhr Universität Bochum \\ Douglas Irvin-Erickson \\ George Mason University \\ Melanie O'Brien \\ University of Queensland \\ Randle C. DeFalco \\ University of Toronto Faculty of Law
}

Follow this and additional works at: https://digitalcommons.usf.edu/gsp

\section{Recommended Citation}

Gudehus, Christian; Irvin-Erickson, Douglas; O'Brien, Melanie; and DeFalco, Randle C. (2016) "Editors' Introduction," Genocide Studies and Prevention: An International Journal: Vol. 10: Iss. 2: 1-2.

DOI:

http://dx.doi.org/10.5038/1911-9933.10.2.1445

Available at: https://digitalcommons.usf.edu/gsp/vol10/iss2/3

This Editorial is brought to you for free and open access by the Open Access Journals at Digital Commons @ University of South Florida. It has been accepted for inclusion in Genocide Studies and Prevention: An International Journal by an authorized editor of Digital Commons @ University of South Florida. For more information, please contact digitalcommons@usf.edu. 
In June 2016 shortly before the International Network of Genocide Scholars (INoGS) Conference in Israel, the Journal for the Study of Antisemitism published a piece by Israel Charny. In his article-based on an online survey and his readings of some articles-Charny declared the Journal for Genocide Research as biased. More concretely, he stated that the journal publishes articles that minimize the Holocaust and/or are anti-Israel and anti-Zionist. Charny refers explicitly to several articles, and names their authors. The Genocide Studies and Prevention (GSP) Editorial Board has decided to give the Senior Editor of the Journal for Genocide Research, Dirk Moses, and the authors named in Charny's article the room to react to the criticism. Their submission underwent an internal review by the Editorial Board of GSP and was accepted for publication.

In addition to this response piece, this issue contains five research articles, covering a wide variety of subjects. Eltion Meka addresses the question of minority rights and the interplay of European integration and ethnic reconciliation in Macadonia. Genevieve Parent evaluates the psychosocial consequences of genocide denial in the aftermath of extreme violence in Bosnia and Herzegovina. In their article, Riccardo Armillei, Nikki Marczak, and Panayiotis Diamadis explore two so-called hidden genocides, those of Assyrians and Romani within the wider contexts of the rather well known Turkish Genocide of Armenians and the Holocaust, respectively. And, finally, two articles seek to expand the scholarship of the Rwandan Genocide in new directions. Claudine Kuradusenge discusses the Rwandan Hutu diaspora in Belgium and its struggles to relate to the former motherland and the genocide, while Daniel Rothbart and Jessica Cooley investigate the motivations of rescuers during the Rwandan Genocide.

This issue also features for the first time a research field note in GSP'S "State of the Field" section. This section contains essays written by expert practitioners and scholars that are relevant to the current state of research and practice in the field of atrocity, violence, and genocide preventionbroadly and inclusively defined. In this issue, anthropologist Julie Fleischman describes her ongoing work with human remains from the Cambodian Genocide.

The wide range of topics, disciplines, histories (both geographically and temporally), and author nationalities and institutional affiliations, demonstrates not only the widths but also the internationality of the field of genocide studies. Several years ago, the Executive Board of the International Association of Genocide Scholars (IAGS) - taking advantage of new European Union tenure requirements to publish in open access double-blind peer-reviewed journals, and the demand around the world to make scholarship of the highest qualify free and accessible through digital formats-decided to partner with university publishers and platforms that could support the distribution of GSP as an open-access journal. This decision has yielded important results. As of October 2016, GSP has surpassed 43,000 unique downloads in the past year. IP addresses downloading issues of GSP have been recorded from academic institutions on every continent on in the world. Individual articles-especially on understudied cases-have been downloaded over 3,000 times. For example, Kjell Anderson's article on West Papua in Issue 9.2 has been, to date, downloaded nearly 3,100 times. This represents tremendous reach for a scholarly journal, with levels of readership that rival major disciplinary publications. As a result of this new global readership, GSP is beginning to receive manuscript submissions from scholars all over the world. Looking ahead to 2017, we at GSP are excited to continue cultivating and sustaining a global conversation on the prevention and study of genocide, mass violence, and other issues closely related to our field.

\section{Mentorship Program}

$G S P$, in partnership with the IAGS Executive Board, is pleased to announce a mentorship program for emerging scholars. In its early stages, the mentorship program will focus on assisting emerging scholars (i.e., students in graduate programs who intend to work in genocide studies; post-doctoral researchers; non-tenure-track Ph.D. holders; and recently-graduated scholars who are within the first three years of their first professional position) with advice on preparing a specific piece of work for publication.

The manuscript in question should be of regular journal length and at a stage where it is very near ready for publication. Manuscripts that are underdeveloped, improperly formatted, or in a 
state that is far from being suitable for external peer-review, may be denied access to the mentoring program until they are revised. To support this program, IAGS and GSP are seeking the following:

- Volunteer, established scholars, who are IAGS members and are willing to work with an emerging scholar in readying a journal article or book chapter for publication. Please send us your name, contact information, areas of expertise, and the languages you are able to work in. You will not be asked to work with more than one emerging scholar per year, unless you specifically state your willingness to do so. If you receive a manuscript that you feel is not yet ready for mentoring, you may request it be returned to the emerging scholar for further revision.

- Emerging scholars who would like advice from an established scholar to help ready a journal article or book chapter for publication. Along with your name and contact information, please send an abstract for the specific piece for which you would like to be mentored and the language in which you would like to mentored. We will do our best to accommodate your request, but remain dependent on the availability of a suitable mentor.

GSP will also refer journal submissions to this program when they receive articles that show promise, but require further polishing before being distributed for peer review. Publication in GSP is not guaranteed through this program. This is a volunteer-based program solely designed to build helping networks between established and emerging IAGS scholars - it is not available to non-members.

Please send all information to awoolford@genocidescholars.org, Andrew Woolford, IAGS President.

Christian Gudehus

Douglas Irvin-Erickson

Melanie O'Brien

Randle DeFalco 